\title{
What MOtivates us to DEVElop the Focus on Open SCIENCE SERIES?
}

\author{
Tiberius IGNAT
}

Open Science describes the current transition in how research is undertaken, how the outputs are stored and disseminated, how researchers collaborate, how success is measured and how researchers are rewarded for more transparent and collaborative approaches. Open Science has the potential to transform the research landscape. This potential has been successfully tested - if only that - during pandemic times.

In 2015, Scientific Knowledge Services (SKS) together with the Library of the University College London (UCL) started an initiative of organising a series of events that aimed to discuss the principles of Open Science at the local level. At that time, it was a significant level of conversation about Open Science at international conferences, but less than necessary at the level of organisations. Moreover, the international supporters of Open Science were more focused on activism while the practical implementations were rare. We couldn't identify consistent events dedicated to Open Science at the local level, at that time. At best, this new approach for research was making a frail presence in conferences dedicated to other topics of research administration and support. Therefore, we thought that building up a series of events focused on Open Science and bringing the conversation at the local level, sounds like a good idea.

Supporting Open Science wasn't an obvious route for Scientific Knowledge Services. As an academic content provider, we represented (and still do) publishers and other organisations that sell their content under a business model which was almost entirely based on subscriptions. Changes were underway, but this was the most common situation in 2015. Our many years of membership in LIBER (The European Association of Research Libraries) gave us a better 
understanding of the research culture, especially how research is funded, evaluated, supported and what are the expectations from research organisations, at the European level.

We were convinced that fundamental research should move from a competitive landscape measured with proxy indicators to a new architecture that includes precompetitive collaborations at its heart. Applied research, engineering, drug development and many other innovation fronts have plenty of reasons to develop a competitive environment, but the fundamental research should be run on different principles. It is a knowledge layer that needs to be available to the entire research community and - to a large extent - to the broader population.

Even today, 7 years later and 33 chapters away from our first Focus on Open Science event, we feel that a part of the scholarly communication community still asks why SKS got involved in such an endeavour. What is the secret ingredient that keeps us motivated? We respond to that by defending the role of private initiatives in the development of a better world. As we will see, Open Science is first of all a cultural change. It goes to the core of research which was based for centuries on a culture of secrecy. Such a change - from secrecy to openness - can't be made just by a part of our society. It is a complex transformation where everyone should play a role - including private companies - and SKS humbly thinks that we can contribute to transforming research into a more transparent, trustful and participative process. Building a better world is neither the burden, nor the prerogative of the public or non-governmental institutions. On the contrary, it is the responsibility of all of us.

The Focus on Open Science series is not the only venue where we make an effort that contributes to the cultural change in research. For example, we created a workshop to the prestigious OAI Conference (CERN-University of Geneva) in 2019 to discuss how to rightly balance collaboration and competition in research and we presented our proposals at annual conferences like UKSG (UK Serials Group), 
ECSA (European Citizen Science Association) and LIBER to convince larger audiences that every pillar of Open Science matters (including Citizen Science).

Before continuing to present the experience we built during the 7 years of Focus on Open Science (counting on/still counting), we are presenting here some of our views on Open Science, trying to make it clear to the readers of this volume why we are so engaged in this cultural change.

Ideally, research is building an economy of trust in which evidence represents the currency. Researchers seek to find new evidence about nature and society and exchange such evidence within the system (e.g. for technology transfer, for research assessment, for career development) and outside the system (e.g. with policymakers, funders, journalists, schools, etc.). The evidence itself is endorsed by peer-review, a centuries-old process in which researchers discuss the scientific conclusions in expert conversations. There's no doubt that building trust and exchanging evidence requires great transparency.

On the other hand, our society is not designed to grant trust. No reasonable person expects to obtain trust just by asking for it. Our society is set in such a way in which individuals and organisations work hard to acquire the confidence of others. At the same time, the entire society requires evidence and demonstration before establishing trust.

In less words, research requires trust, but trust is obtained hard. We, at SKS, remain hard to be convinced that perpetuating a culture of secrecy for the field of fundamental research is making the research ecosystem run smoothly. If it doesn't run smoothly, the research system is slow and incapable of matching societal needs.

It is worth mentioning here a front that is less developed by the research community, at the global level. The researchers are at best able to establish new evidence. Such evidence represents current 
understanding about, for example, a phenomenon, historical event, behaviour, etc. Researchers are not in the position to discover the ultimate truth about such elements of their investigations. They only discover, discuss and establish new evidence. This is why it is very common that current research contradicts past evidence. This situation is not sufficiently explained and understood by the rest of society. Missing such a fundamental building block, trust in research will always suffer because our society could easily confuse research progress (new evidence) with a lack of consistency (contradicting past evidence). This is a typical area for Open Science, as a new culture, to engage in the change. Connecting science with society is usually tackled through Citizen Science, but other pillars of Open Science could make a great contribution, too.

Equally important, the quality in research should raise and not decrease as we move to more transparency and accelerated discoveries. Some Open Science activists believe that the quality of research is safeguarded by self-regulatory mechanisms that are developed unmediated in an "open" environment. We have a different opinion. With the rise of misinformation, disinformation and algorithmic persuasion (machines persuading humans) we identify as a high risk the idea of looking for self-regulation in Open Science, to increase the quality of research processes. Open Science offers the prospect of full disclosure and accelerated discoveries, but alone, it doesn't offer a solution to increase the quality of research. It should remain attached to certain principles (like peer-review, reproducibility and others) in order to responsibly serve societal needs.

Open approaches were introduced in science in the sixteenth and seventeenth centuries. Before that, a number of elements (or the lack of them) encouraged a situation in which knowledge was only available to a small group of people. It was typical for the Pythagorean and Aristotelian traditions to share knowledge exclusively with elite disciples. As the Oxford Companion to the History of Modern Science notes, "the hermetic philosophy of the Renaissance reserved the secrets 
of nature for initiates in a similar way as craft techniques were locked in the artisan's workshops. In the same period, the absence of intellectual property rights was a great barrier that determined the engineers and inventors to keep their work unpublished or secretly preserved".

The scientific revolution changed that status for knowledge. The newly invented printing press made possible a wider availability of text and knowledge. Italian city-states developed patent laws in the fifteenth century. The seventeenth century brought to the world the scientific societies (Royal Society of London and the Académie Royale des Sciences in Paris) that provided the practical avenue of publication through their journals and promoted the idea that researchers communicate their work in communities of peers ${ }^{1}$.

Against all those new open approaches to knowledge the culture of secrecy is still very much present in research. Making knowledge available is simply not enough to create transparency in research. This culture of secrecy which we challenge is preserved today through 3 vectors ${ }^{2}$ :

1. personal secrecy, motivated by an unjust rewards systems, mainly based on proxy indicators, and by the informal "reputation economy" of research (some call it "research vanity");

2. industrial secrecy which is stimulated by the possible rewards for the ownership of discoveries;

3. military and security interests for which research activities have always delivered a competitive edge.

Open Science represents a different culture to the secrecy of science and should be considered similar in size to the changes of the seventeenth century. But it is no less difficult to produce this cultural change than

1 The Oxford Companion to the History of Modern Science https://www.oxfordreference.com/view/10.1093/ acref/9780195112290.001.0001/acref-9780195112290

2 idem 
it was 500 years ago, therefore it's important to understand its real challenges and opportunities.

Although science became increasingly open, beginning with the seventeenth century, it is only lately that "Open Science" became a concept that promotes more transparency in science. Here is a short evolution of this concept, in a chronological presentation that doesn't pretend to be comprehensive:

- 1998: Prof. Steve Man from the University of Toronto coined the term "Open Science" as a possible solution to address the need for truth and open disclosure ${ }^{3}$.

- 2012: The Royal Society publishes Final report - Science as an open enterprise led by Regius Prof. Geoffrey Boulton ${ }^{4}$

- 2013: Two critical articles were published by The Economist in October 2013 to disapprove the lack of transparency in research:

- Trouble at the $l a b^{5}$

a How science goes wrong ${ }^{6}$

- 2015-2016: Nature's How Scientists Fool Themselves ${ }^{7}$ and the 1,500 scientists lift the lid on reproducibility ${ }^{8}$ were published 2 years after The Economist critiques;

- 2016: The European Council's The transition towards an Open Science system $^{9}$ was adopted in 2016. It represented the next step of the public consultation Science 2.0: science in transition ${ }^{10}$ which is hard to access today on the European Commission's servers (an

3 Mann, S., Janzen, R., Rampersad, V., Huang, J., Ba, L. J., "SQUeAKeys": A friction idiophone, for physical interaction with mobile devices," 2015 IEEE Games Entertainment Media Conference (GEM), 2015, 1-4, DOI:

https://doi.org/10.1109/GEM.2015.7377235

4 https://royalsociety.org/-/media/policy/projects/sape/2012-06-20-saoe.pdf

5 https://www.economist.com/briefing/2013/10/18/trouble-at-the-lab

6 https://www.economist.com/leaders/2013/10/21/how-science-goes-wrong

7 https://www.nature.com/articles/526182a

8 https://www.nature.com/articles/533452a

9 https://data.consilium.europa.eu/doc/document/ST-9526-2016-INIT/en/pdf

10 https://ec.europa.eu/digital-single-market/en/news/science-20-sciencetransition 
example of bad practice of Open Science, in which the "record preservation" practice in policy commons was left behind);

- 2020: The European Commission's expert group "Open Science Policy Platform”, led by Prof. Eva Menez from the University Carol III de Madrid published its final report which includes a valuable set of recommendations: Progress on open science: Towards a shared research knowledge system: final report of the open science policy platform ${ }^{11}$.

Today, the European research stakeholders tend to accept the description of Open Science given by the European Commission when it started to work close with two expert groups (the Open Science Policy Platform and the Horizon 2020 Commission Expert Group on Indicators for Researchers' engagement with Open Science) ${ }^{12}$.

The eight ambitions of the European Commission became the eight pillars of Open Science that still define the movement today in Europe:

1. FAIR Data,

2. Research Integrity,

3. Next Generation Metrics,

4. Future of Scholarly Communication,

5. Citizen Science,

6. Education and Skills,

7. Rewards and Initiatives,

8. The European Open Science Cloud.

It is worth noting that 2021 opens a new era for research ambitions. The COVID-19 pandemic, climate crises, the steps back in globalisation and an increasingly tense situation for securing economic dominance between USA and China made governments more aware of the potential of scientific outbreaks. We are now only 9 years away from measuring

11 https://op.europa.eu/en/publication-detail/-/publication/d36f8071-99bdllea-aac4-0laa75ed7lal

12 https://ec.europa.eu/info/research-and-innovation/strategy/ strategy-2020-2024/our-digital-future/open-science_en 
the success of the United Nation's Sustainable Development Goals (SDG) programme which poses goals that are harder than ever to be reached (by 2030). Some governments are looking to replicate the scientific leap of the $60 \mathrm{~s}^{13}$ and this may have an unpredictable impact on the development of Open Science. On the other hand, UNESCO has drafted a set of recommendations to their members which is expected to be adopted in November 2021. Whether the changing culture of research will continue to head toward Open Science or science will shift to something else, the need for increased transparency to the inner parts of discovery remains a basic need. These developments make us both optimistic and concerned about the future of Open Science.

Finally, the readers of this chapter are encouraged to search and continuously update themselves with the variety of national and international strategies for industry ${ }^{14}$, healthcare ${ }^{15}$ and for defence ${ }^{16}$ and to place the Open Science transformation in such larger contexts of heralded ambitions.

\section{Focus on Open Science: A Series dedicated to SANe change}

When we decided to invest and develop a series of events dedicated to Open Science, we strongly believed that the Open Science movement started as a vision, aiming to address matters like research reproducibility and access to the results of publicly-funded research. We saw that the vision was generally welcomed by academic and research institutions and benefited from a great advocacy movement. At the same time, we were convinced that it was the right time to start building on practice and effective management. Moving from vision and activism to designed advocacy and management represented

13 https://www.economist.com/science-and-technology/2021/06/03/a-growingnumber-of-governments-hope-to-clone-americas-darpa

14 for EU: https://ec.europa.eu/info/strategy/priorities-2019-2024/europe-fitdigital-age/european-industrial-strategy_en

15 for UK: https://ukhealthcare.uky.edu/strategic-plan-2025

16 for EU: https://eeas.europa.eu/topics/common-security-and-defence-policycsdp_en 
for us the needed step to see Open Science in practice, confronted and validated by research communities. We gave great respect to the determination of policymakers and the enthusiasm and support of research administrators to introduce Open Science, but at the same time we knew that the ultimate game changers are the researchers and their communities. And this is what we insisted on: to have the deep conversation of Open Science carried on to the local research communities. Many of our chapters were organised in collaboration with research libraries and we insisted they reach their researchers (readers) and invited them to the series, including both groups: supporters and scepticals of Open Science. Listening and understanding each one's opinion is a key factor to shape the implementation path of this new research approach.

It is generally accepted in Europe that research should be as open as possible and as closed as necessary. Therefore, understanding the dynamic border between the two is one of the most important tasks for practitioners, whether they belong to funders, research organisations, their partners or researchers themselves. Yet, this borderline is not sufficiently explored. Guidelines based on feedback and learning from practice should be created sooner rather than later.

Organising the Focus on Open Science series, we learned that this innovative approach to research has further potential: to address existing inequalities and matters like inclusivity, ethics, better assessment or the missing links between science and society or to re-shape public-private partnerships.

But all these tasks and ambitions are hard to be managed without bold leadership, endurance and sometimes suffering. Although we like to believe that Open Science could deliver immediate and positive results, to uncover a road of discoveries that has never been seen before, the reality that we learned by meeting so many research communities is that Open Science is a difficult, costly and sometimes unpredicted journey. We've noticed that the opportunities it poses are clear and generally similar 
across disciplines and research communities, but the challenges are more diverse and most likely to be overlooked, especially in the bottomup approaches. It is on the leader of institutions to show determination and overarching approaches to support the implementation and the sustainability of this new culture. Lab-created solutions proved to be innovative and sometimes very practical, but without exception they met the struggle of sustainability. They need to gain support from the top management of institutions, to attract human talent and expertise and to secure development funds that exceed project cycles.

We continue to believe that by organising the Focus on Open Science Series in various European communities, we contribute to design local roadmaps for practical and responsible implementation of Open Science.

Soon after our first chapter (Ljubljana, 2015; organised with CTK Ljubljana), we decided to form a Steering Committee to help us keep the right course and tackle the most relevant topics for research communities across regions. Our current Steering Committee has the following members:

1. Dr Paul Ayris, Pro-Vice-Provost (UCL Library Services), Chief Executive, UCL Press, co-Chair of the LERU INFO Community (League of European Research Universities).

2. Frank Manista, European Open Science Manager, Jisc, UK.

3. Jeannette Frey, Director of BCU Lausanne and President of LIBER (Association of European Research Libraries).

4. Colleen Campbell, Open Access 2020 Initiative, Max Planck Digital Library.

5. Dr Ignasi Labastida i Juan, Head of the Research and Innovation Unit of the CRAI at the University of Barcelona (Learning and Research Resources Centre).

6. Dr Tiberius Ignat, Director of Scientific Knowledge Services.

7. Additionally, our local partners will be able to delegate a member to join our Steering Committee with reference to the respective event that will take place in their country. 
For the same reason, we approached LIBER in 2016 and agreed in 2017 on collaborating on this series, promoting each one's effort to communicate the opportunities and challenges of Open Science.

We trust that collaborating with such prestigious institutions, with a proven record of supporting Open Science, allow the series of Focus on Open Science events to remain relevant. We deeply understand that the real-life transformation is posing unforeseen challenges that could be better answered if a strong bond exists between research performing organisations, funders, research support organisations and offices and the Focus on Open Science series.

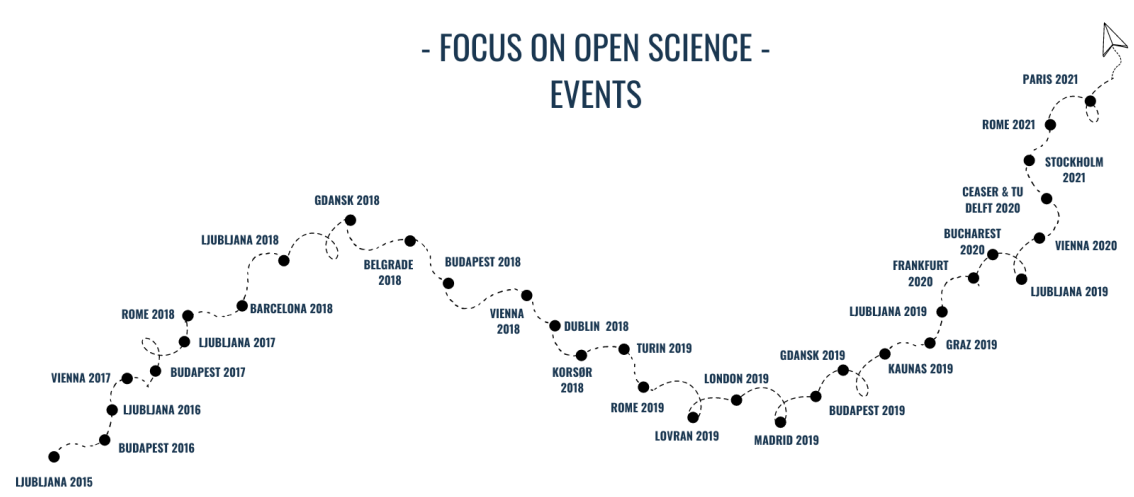

Figure 1. An illustration of all Focus on Open Science events between 2015-2021. Updated: August 2021

During our events, we typically emphasize the research practices and discuss the role of research organisations to support this transition, both acting locally and internationally. 
Starting in 2019, the results of the workshops were captured in formal reports. These reports are intended to be used by all involved partners (not only by organisers), to advance the implementation of Open Science in their communities and their own institutions.

The language of these events is English, but we encourage the audience to pose their questions in their own language if it's easier. To make this work, we received the great support of the audience so far, to translate the questions to the panelists.

The events' format offers both on-the-spot interactions and future networking opportunities. The interactive part has been particularly increased with the transition to "online by default". The online platform is easy to use, without the need to install complicated software or create additional accounts. It offers networking opportunities similar to physical events, including one-to-one videos, while the participants remain in control of deciding with whom to interact. This is probably not the best place to describe the detailed arrangements of the online platform as a successor of the physical events' format, but it is important to let the reader of this chapter know that at the core of our events are the attendees and everything their participation consist on: the knowledge they exchange, the dialogue they create and the networking opportunities they build.

In terms of geographical representation, we first thought that a deeper dialogue about the implementation of Open Science is mostly needed in Central and Eastern Europe. We were wrong (maybe biased?). Figure 2 shows the distribution of our events, as it was requested by institutions in various European countries. Today, we mostly receive requests from Western and Northern Europe which suggests the hot spot for Open Science in Europe. We are convinced that Europe needs to move together in this transformative journey of research and our ambition is to support all interested communities. We would very much like to see that no stone remains unturned in the process of understanding how to best achieve the needed transparency in research, no matter where these stones are, in terms of geographies or research disciplines. 


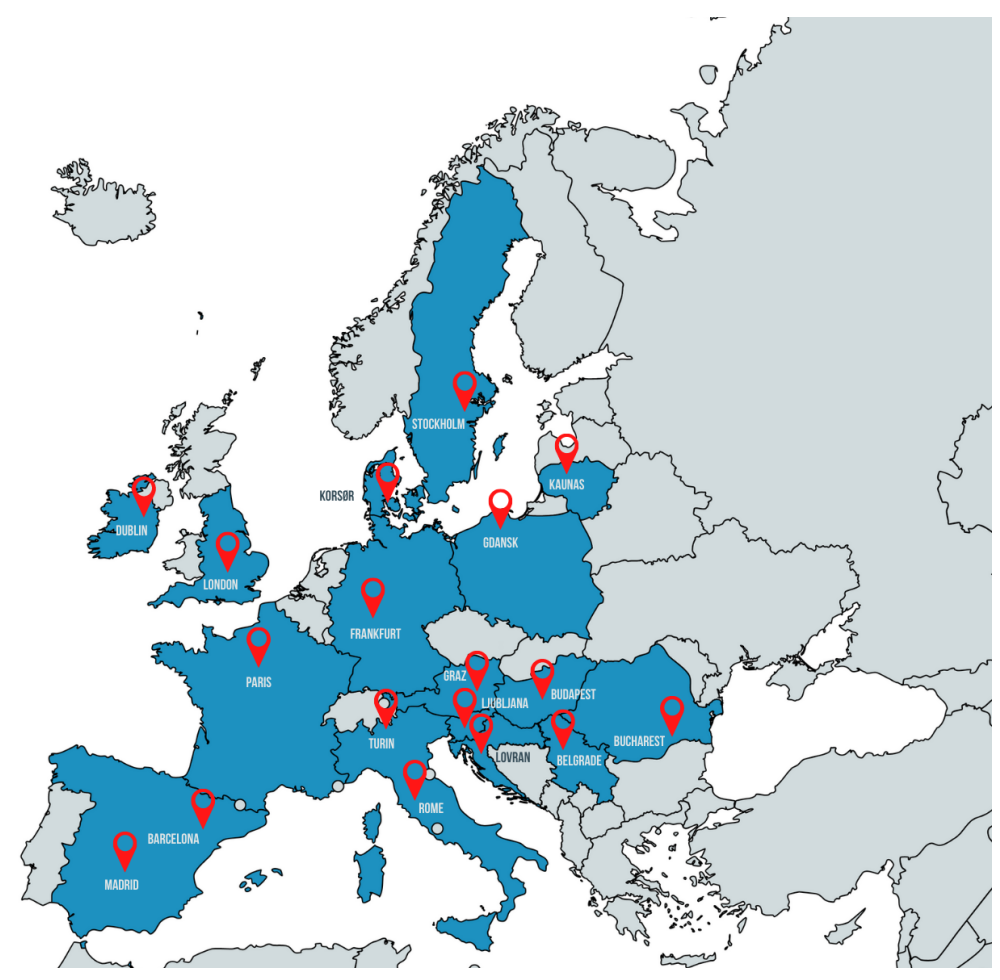

Figure 2. The Geographical distribution of Focus on Open Science chapters between 2015-2021. Updated: August 2021

All our events (or "chapters", as we call them) are organised with a local partner which gives also a member of the steering committee for that chapter. In Hungary, the traditional partner of the Focus on Open Science series was the Electronic Information Service National Programme (EIS) ${ }^{17}$ hosted by the Library and Information Centre of the Hungarian Academy of Sciences. This collaboration made it possible to organise 4 events, between 2016-2019, a series which was interrupted only by the COVID-19 pandemic. Each of the events gathered around 120 participants from all over Hungary and from abroad. The quality of the programme and the proximity of other events organised by EIS right after the Focus on Open Science chapter expanded the attendance from national to international level.

17 http://eisz.mtak.hu/index.php/en/about-us3.html 
Some of the reported notes and recommendations after 4 years of Focus on Open Science in Hungary are:

1. Pan-European approaches are needed

a. For Open Science to be a success, the concept needs to be embraced in all European countries; otherwise, Europe will lose the leadership role that it currently enjoys.

b. Hungary's reaction to Plan S firmly places its current activity in a European and even broader international context.

2. The Future

a. Open Science represented the future for scholarly activity in universities, underlining the importance of effecting a sustainable transition in an academic culture which is required to deliver success.

b. The timescale required to deliver this change in culture amongst all stakeholders is not short.

3. Rewards and Evaluation

a. The academic culture can only embrace Open Science if there is a consequent change in Reward and Evaluation practices. Using journal metrics alone, for example, as a surrogate for academic quality is simply not helpful.

4. Leadership

a. For Open Science to succeed, there needs to be a fundamental change in how research and education are performed, recorded, shared, published, evaluated and rewarded. This change can only take place where there is a clear pattern for leadership in Open Science in European countries.

5. Advocacy and Training

a. Open Science practice is best established at the university level where there are advocacy and training programmes to support it. Significant practice across Europe shows that such activities are successfully led by the university library - which is well placed to offer leadership in this area to all players in the Scholarly Communications arena. 
6. Self-Evaluation

a. Universities should undertake annual self-evaluation of their progress in all eight areas of Open Science, as identified by the European Commission and assess their progress in building up all eight pillars of Open Science activity.

\section{Focus on Open Science After the PANDemic OUTbreak}

Between 2015-2019, all Focus on Open Science chapters were physical events, with some online participation, mostly driven by the Budapest and Ljubljana chapters, where local organisers broadcasted the events over the internet. We gathered an overall audience of a bit more than 3000 participants.

An effect of the 2019 pandemic outbreak was for us to cancel 3 chapters in 2020: Rome, Budapest and Antalya (ANKOSLink). It was a difficult decision which motivated us to discuss further changes with the Steering Committee.

First, we revisited the mission statement and the goals of this series.

Our new mission is to contribute to building more autonomy for science and scholarship through Open Science. Research becomes ever more elitist if a small number of people decide what the worthwhile and valid projects are ${ }^{18}$. By building a bridge of trust between researchers and the public, eliminating data manipulations, paywalls to trustful knowledge, and redesigning its reward systems, Open Science is making a grand commitment to better serve the world. Open Science has the responsibility to step up and lead the effort of keeping misinformation at bay. If only for these reasons, science deserves an autonomous place

18 Molloy, J., Liboiron, M. (n.d.), We need to break science out of its ivory tower here's one way to do this. [online] The Conversation. Available at:

https://theconversation.com/we-need-to-break-science-out-of-its-ivory-towerheres-one-way-to-do-this-76354. 
in our society. Our society needs to gain the right to discover, the right to know and the right to develop new solutions that transform our world for the better. Today, such rights are not clearly guaranteed. Research is only granted and commissioned to push the frontier of our knowledge. It needs more than that: the right to do so.

As we set ourselves this new mission, our goals are to address the challenges and opportunities posed by Open Science in this new context. The major difference between what we did in the past and what we do now is the increased interaction with academic societies, NGOs, mass media as well as stronger connections with institutions and individuals that provide education and knowledge.

Second, we decided on a new format: digital by default.

We believe that this new format will help us to create more inclusive and sustainable conversations and to trigger more actions and interactions. Each community we engage with has the chance to promote the events to more participants, including those that were previously not able to travel or to allocate enough time to attend our events. The same effect will be produced for our contributors (speakers, chairs, panelists). The new format is also more environmentally friendly and eliminates unnecessary consumerism. These two topics are increasingly relevant for researchers and for the public. We don't exclude the possibility of having on-site events in the future, but we decided to set the digital model as the default model from 2021 onwards. The on-site meetings could be redesigned, to accompany the digital event, be focused on decision-makers and to trigger institutional changes.

\section{CONCLUSions AND A POSSIBLE PATH FORWARD}

On the cultural level, for Open Science to become a reality, all stakeholders should advocate for it and implement measures that bring more transparency on the research endeavours. On the executive 
side, they need to determine what should be the collaboration and the competition areas for research organisations, funders, nations and societies.

For years, research and innovation delivered the competitive edge of organisations and nations. It grew as a profession embedded in a culture of secrecy. While Open Science started with the dissemination of research output in journals and letters in the middle of the $17^{\text {th }}$ century (Denis de Sallo, Journal de Savants) it was only in the end of 80 s when researchers started to advocate more solidly for a culture of transparency, including the research data, methodologies, protocols, etc. It was only very recently that researchers started to register their reports before starting data collection and committed to publish the negative results.

The funders, the research organizations, the researchers themselves but also the private sector (a massive contributor to the $R \& D$ investment) now realize the potential of research transparency and the value of pre-competitive collaboration. Open Science represents a blueprint for all involved stakeholders and it deserves an intensive effort to be transformed in a new research culture.

Organising the Focus on Open Science series, we understood the need to pass from rhetoric to practice (for the Open Science transformation). This process is currently done in an heterogeneous way. While the funders show a high level of determination, the research organisations need to build more understanding and leadership. It requires a long term vision for research organisations to not only embrace the principles of Open Science (rhetoric), but also to support the researchers in this transformation (practice). This is a topic which we currently focus on.

By running this series across Europe, we had the opportunity to understand that the researchers remain the most vulnerable stakeholders in regards to this transformation. A reformed system of evaluation in research, including new metrics (more inclusive and 
less proxy-patterned), more support to early careers and a research infrastructure more versatile towards research data are just a few features that need to be changed to effectively deliver capacity for Open Science and further on, individual support for researchers.

We also learnt that the research community (including administration, funders and support organisations) faces an urgent need to separate hype from hope in what Open Science is expected to deliver. An example is the trend of introducing the prefix "open" to all research activities and supporting "open to everything" unconditionally. We agree that a transparent society is an ideal place to live, but society needs to meet certain requirements before being able to live in full disclosure. Take the research data. In today's world, FAIR Data ${ }^{19}$ makes much better sense than Open Data.

Not lastly, the experience of over 30 chapters of this series, built for us the perspective that Europe became a policy laboratory for transforming the research activities from secrecy to openness. This is a courageous act that comes together with responsibilities. While policies could be tested and adapted (if they are wrong), the responsibilities don't have the same luxury. Responsibilities are not tested; they are assumed. This is why we need to be very determined in Europe, for accepting the associated responsibilities of Open Science. Funders and research organisations should assure the researchers that they are prepared to take the responsibilities of such massive cultural change. That includes departing from the idea that Open Science is non-expensive and could be achieved with a handful of volunteers. Taking accountability for the full effect of Open Science transformation is equally important with promoting it or to make it happen.

A possible path forward for the Focus on Open Science series is to help encourage the leadership of research organisations in pursuing the cultural change while professionalising the needed change management programmes that are required to accelerate it.

19 https://www.go-fair.org/fair-principles/ 


\section{Open Science \\ NYÍLT TUDOMÁNY MAGYAR SZEMMEL}


A Magyar Tudományos Akadémia Könyvtárának Közleményei Publicationes Bibliothecae Academiae Scientiarum Hungaricae

$45(120)$
UJ SOROZAT

SOROZATSZERKESZTő

GaÁlné Kalydy Dóra 


\section{Open Science \\ NYÍLT TUDOMÁNY MAGYAR SZEMMEL}

Magyar Tudományos Akadémia

KöNYVTÁr ÉS InFORMÁcIÓs KözPONT

BUDAPEST 2021 


\author{
Szerkesztette \\ GaÁlné Kalydy DóRA \\ Anyanyelvi lektor \\ MóNOK MÁRIA \\ Az irodalomjegyzékeket készítette \\ BudAI-KirÁLY TÍmEA \\ Tipográfia és tördelés \\ VAs ViKTória \\ ISBN 978-963-7451-73-7 \\ ISSN 0133-8862 \\ DOI 10.36820/MTAKIK.KOZL.2021.OpenS
}

Felelős kiadó: az MTA Könyvtár és Információs Központ főigazgatója

Nyomta és kötötte az Alföldi Nyomda Zrt., Debrecen

Felelős vezető: GYöRGy GÉzA vezérigazgató

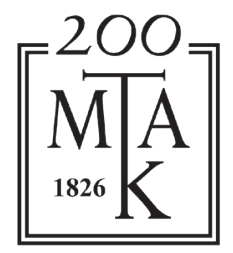

Megjelent a Nemzeti Kulturális Alap támogatásával

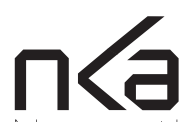

Nemzeti Kulturális Alap 


\section{TARTALOM}

\section{Monok István}

Cui bono, seu cui prodest?

Holl András

A tudományos szakkönyvtárak és a nyílt tudomány

(Open Science)

GaÁlnÉ Kalydy Dóra

A kiadókkal kötött Read and Publish szerződések, és a nyílt hozzáférésű publikálás hazai lehetőségei

Soós SÁndor, Kiss AnNA

Az „Open Access-előnyök" megnyilvánulása

a hazai tudásprodukcióban: bibliometriai hatásvizsgálat

61

\section{GaÁlné Kalydy Dóra}

A közösségi tudomány

\section{Tiberius Ignat}

What motivates us to develop the

Focus on Open Science series?

\section{Hoczopán Szabolcs, Molnár Tamás}

Az egyetemi könyvtárak szerepe a nyílt tudomány

mozgalom elterjesztésében

\section{Holl ANDrás}

Az MTA KIK gyakorlata a nyílt tudomány támogatásában $\quad 161$

A kötetben szereplő tanulmányok szerzői

A Magyar Tudományos Akadémia Könyvtárának

Közleményei, Új Sorozat közelmúltban megjelent kötetei 